\title{
Feed autonomy in organic cattle farming systems: a necessary but not sufficient lever to be activated for economic efficiency
}

\author{
Anne-Michelle Faux • Virginie Decruyenaere • \\ Mary Guillaume $\cdot$ Didier Stilmant
}

Received: 16 April 2020 / Accepted: 7 October 2021 / Published online: 23 November 2021

(C) The Author(s) 2021

\begin{abstract}
Increasing the level of feed autonomy is usually considered as a prerequisite for conversion of cattle farms to organic management. This study is aimed at generating references for organic dairy and beef production through a technical and economic assessment of feed autonomy in commercial farms. Data were collected in 2014 and 2015 on 11 farms located in distinct agricultural regions of Wallonia, Belgium. Dry matter (DM) production, animal performance and all cash in- and outflows were recorded. Economic efficiency (EE) was computed as the share of the feed margin, i.e., the gross product minus the total feed and processing costs, in the gross product. The mean level of mass feed autonomy $\left(\mathrm{FA}_{\mathrm{m}}\right)$ was $94 \pm 6 \%$. Feed production costs $(p<0.05)$ and feed purchase costs $(p<0.001)$ were negatively correlated with $\mathrm{FA}_{\mathrm{m}}$ so that the total feed cost decreased with $\mathrm{FA}_{\mathrm{m}}(p<0.001)$. All farms with $\mathrm{EE}>65 \%$ had a level of $\mathrm{FA}_{\mathrm{m}} \geq 90 \%$; however, one farm with $\mathrm{FA}_{\mathrm{m}} \geq 90 \%$ had a mean $\mathrm{EE}$ of $55 \%$ over both study years. This observation suggested that a $90 \%$ level of $\mathrm{FA}_{\mathrm{m}}$ is necessary, but not sufficient, to
\end{abstract}

A.-M. Faux $(\varangle) \cdot$ M. Guillaume $\cdot$ D. Stilmant Department Sustainability, Systems and Prospectives, Walloon Agricultural Research Centre, rue du Serpont 100, 6800 Libramont, Belgium e-mail: a.faux@cra.wallonie.be

V. Decruyenaere

Department Production in Agriculture, Walloon

Agricultural Research Centre, rue de Liroux

8, 5030 Gembloux, Belgium be economically efficient in organic cattle farming. Four production systems with $\mathrm{EE}>65 \%$ and thus $\mathrm{FA}_{\mathrm{m}} \geq 90 \%$ were finally characterized based on the observed crop rotations, overall DM yields, stocking rates and animal performances.

Keywords Dairy $\cdot$ Economic efficiency $\cdot$ Feed autonomy $\cdot$ Organic farming systems $\cdot$ Selfsufficiency $\cdot$ Suckler

\section{Introduction}

Feed autonomy relates to the ability of a farm to produce livestock from its own feeding resources (Rouillé et al. 2014; Lebacq et al. 2015). In this paper, we used the term 'feed' to refer to both fodder and concentrates for cattle feeding. Feed autonomy is the share of self-produced feeds in the total amount of consumed feeds, including both self-produced and purchased fodders and concentrates. Depending on whether the amounts are expressed in kilograms of dry matter or of proteins, we refer to mass autonomy or protein autonomy.

In organic cattle production, regulatory constraints, high input prices, product quality-related reasons, compel or motivate farmers to consider feed autonomy. European organic farming regulation stipulates that livestock shall have permanent access to open air areas, preferably pasture, whenever the soil and climate conditions allow for it. In addition, at least 
$60 \%$ of the consumed dry matter must come from the production unit itself, or if this is not possible, be produced in cooperation with other organic farms in the same region. Also, at least $60 \%$ of the dry matter must come from roughages (with an exception for milk production, this percentage can be reduced to $50 \%$ at the beginning of lactation for a maximum of 3 months) (Commission Regulation (EC) No. 889/2008).

Regarding the input prices, organic concentrates are particularly expensive (Benoit and Veysset 2003; Lebacq et al. 2015; Experton et al. 2017). As a result, in order to support their profitability, organic cattle systems are more autonomous in concentrates than conventional, non-organic, systems (Paccard et al. 2003; Lebacq et al. 2015).

Milk produced in organic farming is richer in omega-3 polyunsaturated fatty acids (alpha-linolenic acid, in particular), carotenoids and vitamins E, B2 and B9 than milk produced in conventional agriculture, due to a greater use of grass and leguminous plants (Duru et al. 2017). For the same reason, meat produced in organic farming, particularly from animals finished in pasture rather than in the barn, has generally higher levels of omega-3 polyunsaturated fatty acids (alpha-linolenic and eicosapentaenoic acids, in particular), carotenoids and vitamins E, B1, B2 and B9 (Duru et al. 2017). According to Duru et al. (2017), the organic label allows indirectly the consumer to identify grass-based animal products.

Increasing the level of feed autonomy means reducing feed purchases by further relying on on-farm produced fodders and concentrates (Rouillé et al. 2014). Self-produced feeds are commonly grazed grass, stored fodders from permanent grasslands, temporary grasslands and/or immature crops, and grains from cereal and protein crops. The achieved level of autonomy depends, in particular, on the soil and climate conditions of the farm, which affect the crop rotation and yields (Rouillé et al. 2014).

Feed autonomy has been assessed in dairy farms in the Walloon region from economic and environmental perspectives (Lebacq et al. 2015). In this study, an economic indicator was used to assess autonomy, i.e., the ratio between cost of inputs related to animal production, crop production and energy use, and the total gross product. Although efficient to conduct an economic and environmental assessment of feed autonomy, this indicator had several drawbacks, namely its sensitivity to market prices (Lebacq et al. 2015). Next to this study, several reports were published on the technical characterization of cattle farms and the achieved level of feed autonomy in Wallonia (Amerlynck et al. 2013; Faux 2016; Lefèvre 2016).

In France, typical diets for dairy and suckler cattle and associated levels of feed autonomy have been extensively described according to the farming system (Devun et al. 2014). Farming systems were defined based on the type of cattle production (dairy vs beef; exclusive breeder, breeder-fattener or exclusive fattener among beef systems), the technical and economic orientation (e.g., herbivores only, mixed crop-livestock), the natural ecosystem, and the importance of maize in the feeding system (Devun et al. 2014).

Low-input dairy systems have been evaluated under conventional and organic management conditions (Coquil et al. 2009; Delaby and Fiorelli 2014). Such systems are characterized by a reduction or suppression of concentrate purchases while relying on the potentialities of the environment, and require adapted animals, i.e., animals with reduced dietary requirements in particular. In this context, the Jersey breed, characterized by a high fertility and low maintenance requirements, dual breeds such as the Montbeliarde or the Normande, or cross-breeds, offer interesting results in terms of milk production and protein content (Delaby and Fiorelli 2014).

The economic profitability of organic suckler farming systems relies on the use of on-farm produced resources, and, in particular, on their capacity to produce their own concentrates (Veysset et al. 2008). According to Veysset et al. (2008), feed autonomy could only be achieved in mixed crop-livestock farms with adapted crop rotations, while the profitability of farms in grassland areas depends on the opportunity to benefit from the added value associated with organic products, which will enable them to purchase non-self-produced feeds.

Considering the above, the present study was aimed at characterizing a diversity of organic cattle production systems and identifying types of production systems showing economically efficient feeding strategies. It relied on a network of eleven organic cattle farms located in Wallonia, Belgium. Three specific objectives were pursued: (i) determining the level of feed autonomy and the technical and economic performance of the farms, (ii) assessing the relationship between 
feed autonomy and economic performance, and (iii) characterizing types of production systems showing economically efficient feeding strategies. The level of feed autonomy was assessed based on a fine characterization of the whole feed production both in terms of quantity and nutritional quality. Results related to the species composition of sown mixtures, the achieved dry matter crop yields, and the nutritional value of selfproduced feeds, are the subject of a companion paper.

\section{Materials and methods}

Farms

Data were collected in 2014 and 2015 from six dairy and five suckler farms located under distinct soil and climate conditions in Wallonia, Belgium. Farms were numbered according to their type - dairy (D) or suckler (S) - and percentage of permanent grasslands (PG) in the utilised agricultural area. Suckler farms S1 and S3 were breeders-fatteners, while S2, S4 and S5 were breeders only.

Farms had diversified breeds. Suckler farms had Limousin (S1 and S3), both mixed Belgian Blue and Salers (S2), mixed Belgian Blue (S4) or Blonde d'Aquitaine (S5) cattle. All dairy farms had Holstein breed cattle, together with mixed Belgian Blue cattle at farm D1 and with crossbreds including Montbeliarde, Normande, Jersey and/or Fleckvieh cattle at farms D2, D3, D5 and D6. In addition to the dairy herd, farms D2, D3 and D4 had a suckler herd, with Blonde d'Aquitaine and mixed Belgian Blue cattle (D2 and D3) or Limousin cattle (D4). However, this suckler herd was a secondary activity: it accounted for 33,15 and $16 \%$ of the total number of LU in farms D2, D3 and D4, respectively, and was about to be sold or was entirely sold at the end of 2015 in farms D2 and D3, respectively. Therefore, animal performance in these farms was characterized by milk production only, while the stocking rate and feed costs expressed per LU were computed by including both dairy and suckler herds.

Feed production and nutritional value

Dry matter (DM) production from PG, temporary grasslands, immature crops and grain crops, was characterized in terms of quantity and nutritional value.
The production of grazed pastures was estimated using the HerbValo framework (Delagarde et al. 2017) with data from grazing calendars. Wrapped and hay bales were counted and weighed, and bunker silos were sized.

All the produced fodders (grazed grass, bales, silos, and grains) were sampled to determine their DM content and nutritional value. Grazed pastures were sampled once per month between May and October. Wrapped bales and bunker silos were sampled at least 1 month after harvest when the silage fermentation process had reached a stable phase. Grain samples were taken from each distinct grain crop. Contents in crude protein (CP), cellulose, starch and crude fat were estimated according to the NIR model developed at the Walloon Agricultural Research Centre (CRA-W; Decruyenaere et al. 2006), and the nutritional value was determined according to the VEMDVE Dutch system (Van Es 1975; Tamminga et al. 1994).

Finally, the overall self-produced DM and protein yields, considering all the areas dedicated to feed production, were determined for each farm.

\section{Animal performance}

The annual milk production in dairy farms was recorded by the farmer and related to the number of dairy cows or livestock units (LU) in the dairy herd. In addition, in both dairy and suckler farms, the liveweight (LW) of each growing animal was estimated to determine (i) the herd size in LU and (ii) the animal performance of suckler herds as the annual LW production expressed per suckler cow or LU.

The LW of each growing animal was estimated by coupling data from annual herd inventories with a growth model. Herd inventories included, for each farm, the gender, birthdate, breed, and arrival and exit dates of each animal. The growth model was parameterized using weighing data from the farms themselves and from the experimental station of the CRA-W. Parameters were estimated per gender and per breed at two distinct levels: (i) over all farms and (ii) when data were available, at the farm scale. In the absence of calibration data from the farm itself for a given gender and a given breed, the breed- and gender-respective parameters estimated over all farms were used. 
Due to lacking weighing data close to birth associated with clearly non-linear growths for young cattle in given farms, a non-linear, Gompertz model (Hoch et al. 2004) was preferred to a linear model:

$L W_{t}=L W_{0} e^{a_{1}\left(1-e^{-a_{2} t}\right)}$

where $L W_{t}$ is the LW of a given animal at time $t$, and $L W_{0}, a_{1}$ and $a_{2}$ are model parameters. $L W_{0}$ accounts for the LW at birth, $a_{1}$ is involved in the estimation of the adult LW, and $a_{2}$ accounts for the rate with which the LW tends toward its maximum value.

Start values for parameters in Equation (1) were provided for each calibration dataset as follows. Let $b_{0}$ and $b_{1}$ be the intercept and slope of the linear regression of weight on age for growing animals, and let $L W_{\max }$ be the maximum LW of adult animals in the dataset, $b_{0}$ was used as a start value for $L W_{0}$, $\log \left(\frac{L W_{\max }}{L W_{0}}\right)$ as a start value for $a_{1}$, and $\frac{b_{1}}{\frac{L W_{\max }}{2}}$, i.e., an estimate of the relative growth rate when $\stackrel{2}{2} W=\frac{L W_{\max }}{2}$, as a start value for $a_{2}$. Bounds were provided for each parameter as follows: $35 \leq L W_{0} \leq 50 \mathrm{~kg}, \log \left(\frac{L W_{\text {max }} \text { lower }}{L W_{0}}\right)$ $\leq a_{1} \leq \log \left(\frac{L W_{\text {max_upper }}}{L W_{0}}\right)$ with $L W_{\text {max_lower }}$ and $L W_{\text {max_upper }}$ being respectively 900 and $1200 \mathrm{~kg}$ for males and 600 and $900 \mathrm{~kg}$ for females, and $0 \leq a_{2} \leq 0.005$, i.e., a value that corresponds to a daily growth of $1.5 \mathrm{~kg}$ achieved by an animal reaching a $L W_{\max }$ of $600 \mathrm{~kg}$.

Finally, the annual LW production of suckler herds was obtained by summing the LW production from growing animals and fattened sold cull cows. The LW gain of cull cows was set at $60 \mathrm{~kg}$ assuming an average daily gain of $1 \mathrm{~kg} \mathrm{day}^{-1}$ (Decruyenaere et al. 1999) over a period of 60 days. The LW gain of growing animals, $\Delta L W$, was obtained by summing, over all growing animals, the weight difference between their arrival and exit dates:

$\Delta L W=\sum_{i=1}^{n}\left(L W_{i, t_{2}}-L W_{i, t_{1}}\right)$

Based on the observed growth curves, animals were assumed to grow until 33 months of age (1000 days old). For a given $i$ growing animal in a given study year, $t_{1}$ was either its birthdate (if born within the year), its date of arrival in the herd (if purchased within the year) or the first of January (otherwise). Exit date $t_{2}$ was either its exit/death date (if sold or dead within the year), its 1000-day-old date or the $31^{\text {st }}$ of December (otherwise).
Stocking rate

Herd size in LU was calculated by considering the animals' energy requirements $\left(\mathrm{VEM} \mathrm{day}^{-1}\right)$ in order to take into account the diversity of animal performances among the farms. Energy requirements of young cattle were determined by coupling their estimated weights (cfr supra) and growths with reference tables for dairy heifers (MCMA 1993), suckler heifers (MCMA 1996), and young males (PDZR 1996), respectively. For cows, they were estimated based on their LW, milk production and gestation requirements according to ILVO's equations for dairy (De Brabander et al. 2011) and suckler cattle (Hubrecht et al. 2013). Cows' LW was set according to the farms' breed and cattle format (Delagarde et al. 2017). It was set at $632 \mathrm{~kg}$ (average LW of mid-sized crossbred cows) in all dairy farms but D6, which had Jersey cattle, with $560 \mathrm{~kg}$ (small-sized crossbred cows). LW of suckler cows was set according to the estimated maximum LW from Equation (1). It ranged between 620 (mixed Belgian Blue cattle in farm S4) and $700 \mathrm{~kg}$ (Limousin, Blonde d'Aquitaine or mixed Belgian Blue cattle in farm S2). Observed milk productions were used for dairy cows, and a milk production of $7 \mathrm{~L}$ per day was assumed for suckler cows (Sepchat et al. 2017).

Energy requirements were converted to LU by considering that one LU corresponds to the requirements of a $632 \mathrm{~kg}$-dairy cow with an annual milk production of 5000 L. The stocking rate was finally obtained by dividing the herd size in LU by the total agricultural area used to feed cattle.

Feed autonomy

The level of mass feed autonomy $\left(\mathrm{FA}_{\mathrm{m}}\right)$ was computed as the share of the self-produced consumed DM in the total consumed DM, including both the self-produced and purchased DM. The purchased DM included mineral and vitamin supplements in addition to purchased fodders and concentrates. Also, the level of protein feed autonomy $\left(\mathrm{FA}_{\mathrm{p}}\right)$ was computed by multiplying, for each purchased or self-produced feed, the consumed amount of DM by its $\mathrm{CP}$ content. 
Economic assessment

Economic performances were computed by considering the feed costs, the costs of product processing, if any, and all cattle-related incomes. They could be determined for 9 out of the 11 monitored farms (farms S2 and S4 had to be excluded because of missing data). All monetary values are provided excluding VAT.

\section{Feed and processing costs}

Feed costs were computed by considering the costs of producing fodders and grains in addition to the feed purchase costs. Production costs were used rather than transfer costs from the crop production unit to the livestock unit to reflect, within the feed costs, the feeding strategy chosen by the farmers during the monitored years, namely, producing cereal-legumes crops or purchasing concentrates.

Feed production costs included costs related to crop inputs (seeds, fertilizers and amendments), fodder storage (plastic for bales and bunker silos, in particular), mechanization (fuel and lubricants, equipment and machinery), work by third parties, as well as, if applicable, the fees related to cooperatives for the use of agricultural equipment (CUAE; coopérative d'utilisation de matériel agricole in French). Mechanization costs were allocated to self-consumed crops, cash crops and cattle by applying the coefficients and methodology described by Charroin et al. (2010). Equipment and machinery costs included both depreciation and maintenance charges. Depreciation charges were however unavailable. Therefore, a depreciation cost, expressed per year and per ha, was estimated for each specific equipment based on data observed in similar farms in Wallonia (Service Public de Wallonie, Direction de l'Analyse économique agricole) and using a depreciation duration of 16 years (MecaCost 2021). Depreciation charges were then obtained, for each farm specifically, by summing the depreciation costs of the equipment needed for the field works carried out by the farmer himself multiplied by the feed production area. In addition, equipment and machinery maintenance charges higher than 500 euros were depreciated on a duration of six years (DAEA 2009).

Feed purchase costs included all expenses in terms of concentrates, minerals, feed supplements (e.g., cod liver oil, algae, sepiolite supplements) and purchased fodders. Product processing costs, if any, included the variable costs associated with milk processing (packaging and labelling fees, possible additional ingredients).

\section{Cattle-related income}

The annual gross product (GP) was calculated for each farm by considering (i) all cattle-related incomes without subsidies, resulting from sales of milk, processed milk, store or fattened live cattle and breeding bulls, (ii) cattle purchases, and (iii) variations in livestock:

$G P(\in)=($ sold milk and processed milk $)+($ sold animals - purchased animals $)+($ closing stock - opening stock $)$

Livestock variations were determined over each accounting year for each category of animals and converted into monetary values by applying the average selling prices per animal category observed in Wallonia in 2014 and 2015 for livestock from organic farms (Service Public de Wallonie, Direction de l’Analyse économique agricole).

\section{Economic efficiency}

Economic efficiency (EE) was finally computed as the share of the feed margin, i.e., the GP minus feed and processing costs, in the GP:

$E E(\%)=\frac{G P-(\text { Feed production and purchase costs }+ \text { Processing costs })}{G P}$

EE was used in the present study because it is independent of both the type of sold product (e.g., milk, 
store cattle, fattened cattle) and the absolute amounts generated, which varied according to the farm's size and type (dairy or suckler).

\section{Data analysis}

Data analysis was conducted in three steps. First, descriptive statistics were computed for each indicator, technical or economic. Technical indicators included the agricultural area, the percentage of PG, the overall DM yield, the animal performance (milk or LW production depending on the farm type, dairy or suckler), the stocking rate, and the level of feed autonomy. Economic indicators included the feed production and purchase costs, expressed per LU, and the EE. Second, relationships between economic indicators (feed costs, EE) and feed autonomy were assessed, and economically efficient farms were identified based on graphical results. Finally, a principal component analysis was conducted on technical indicators from farms showing economically efficient feeding strategies in order to characterize types of economically efficient production systems. The normality of the distribution of the explanatory variables used in PCA was verified by applying a Shapiro test. Data processing and analysis were carried out using the R software package (R Core Team 2018).

\section{Results}

Technical assessment

\section{Agricultural area and overall yield}

Monitored farms had on average $73 \pm 21$ ha of agricultural area (Table 1). The percentage of PG in the total agricultural area ranged between 33 and $100 \%$ in farms D1 to D6, and between 49 and $86 \%$ in farms S1 to S5 (Table 1). The percentage of areas dedicated to feed production was $76 \%$ in farm $\mathrm{S} 1$ and between 91 and $100 \%$ in all the other farms. The overall yield computed over all areas dedicated to feed production was on average $5677 \pm 1261 \mathrm{~kg} \mathrm{DM}$ per ha, made up of $50 \pm 7 \%$ grazed grass, $44 \pm 7 \%$ stored fodders and $6 \pm 6 \%$ grains. In terms of proteins, it was on average $836 \pm 235 \mathrm{~kg} \mathrm{CP}$ per ha, made up of $61 \pm 7 \%$ grazed grass, $34 \pm 7 \%$ stored fodders, and $5 \pm 5 \%$ grains.

\section{Animal performance}

Dairy farms had on average $60 \pm 24$ dairy cows, ranging from 33 (D2) to 101 (D6) (Table 1). In addition, farms D2, D3 and D4 had a herd of $11 \pm 4$ suckler cows, ranging from 8 (D3) to 15 (D4). Dairy farms had on average $90 \pm 20 \mathrm{LU}$, including both dairy and, if any, suckler herds. Suckler farms had on average $45 \pm 11$ suckler cows, ranging from 34 (S1) to 62 (S4), and a total of $52 \pm 9$ LU.

Calibration of Equation (1), i.e., the model used to estimate the weight of growing animals, resulted in an average root mean square of error of $54 \mathrm{~kg}$ across breeds and genders (Table 2). Parameter $L W_{0}$ was 45 or $50 \mathrm{~kg}$ regardless of the gender and the breed with the exception of Blonde d'Aquitaine males for which a lower $L W_{0}$ was obtained. With the exception of crossbred dairy males, parameter $a_{1}$ was higher for males than for females, as expected from their higher maximum LW. Parameter $a_{2}$ did not vary according to the gender. However, it tended to be higher in farm S1 and at CRA-W, which fattened animals. Farm S3, which had Limousin cattle, was the only suckler farm without weighing data to calibrate the growth model. Therefore, animals' weight in farm S3 was computed using Limousin-respective parameters, which were estimated over all Limousin cattle herds (i.e., farm S1 and the CRA-W's experimental farm). We verified that the resulting estimated weights were in agreement with the carcass weights of sold fattened animals that were observed in that farm.

The average annual milk production per dairy cow was $5326 \pm 824 \mathrm{~L}$, ranging from 4029 (farm D2) to 6481 (farm D4; Table 1). Related to the dairy herds' size, it was on average $3839 \pm 544$ litres $\mathrm{LU}^{-1}$. It was the highest at farm D6 because of a low proportion of young cattle in that farm (animals less than 2 years old accounted for $26 \%$ of the total number of animals in farm D6, while they accounted for 40 to $49 \%$ in the other dairy herds). The milk protein content was $3.48 \pm 0.16 \%$, ranging from 3.33 to $3.67 \%$.

The average annual LW production in suckler farms was $216 \pm 64 \mathrm{~kg}$ per suckler cow $(207 \pm 49 \mathrm{~kg}$ per LU) for breeding farms (S2, S4 and S5), which were selling store animals, and $508 \pm 112 \mathrm{~kg}$ per suckler cow ( $347 \pm 42 \mathrm{~kg}$ per LU) for breeding-fattening farms (S1 and S3; Table 1). The low performance found in farm S5 $(151 \pm 20 \mathrm{~kg}$ per LU) was 


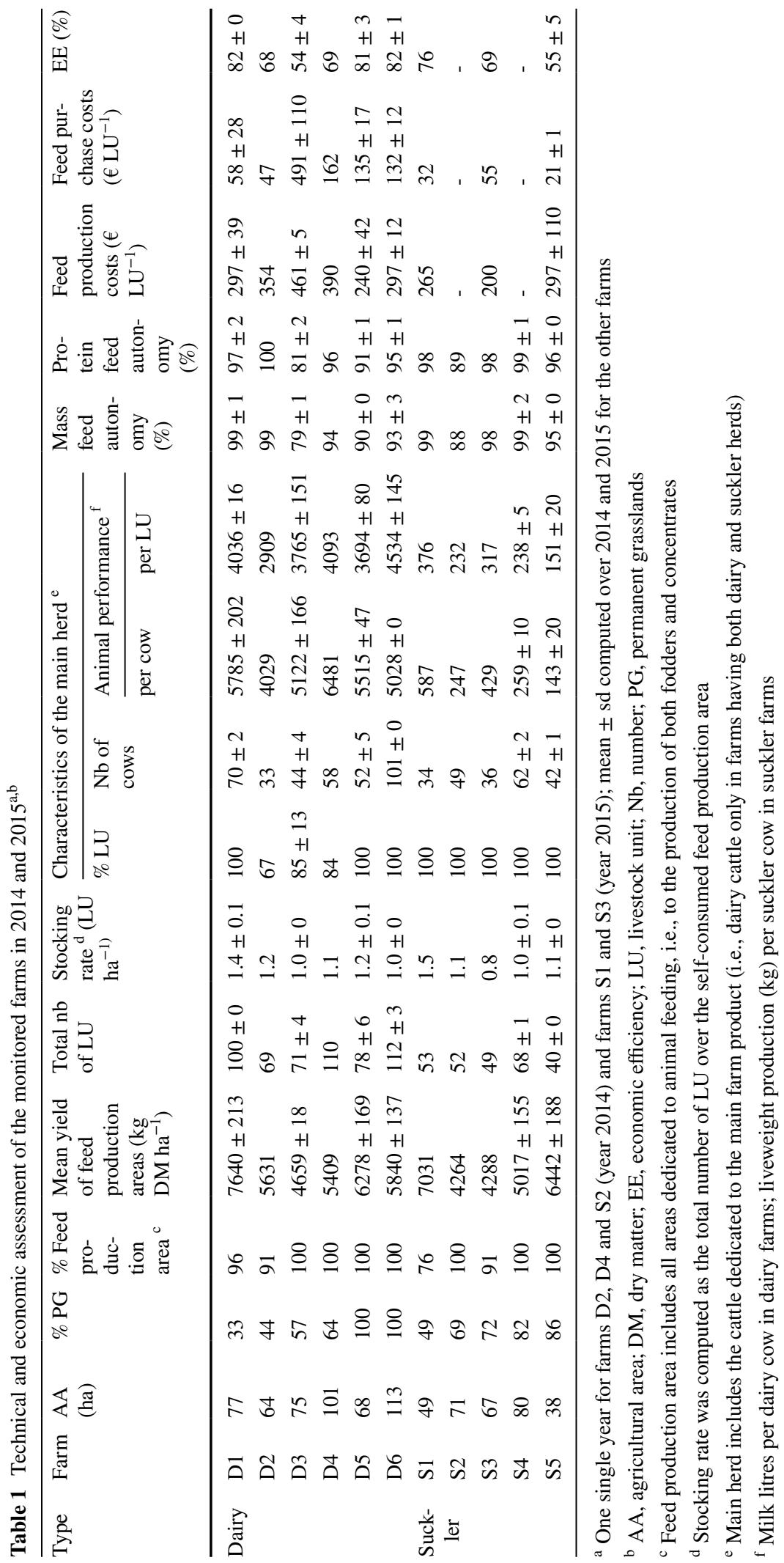


Table 2 Number of animals, parameter estimates of the Gompertz function used to model the young cattle growth $\left(\mathrm{LW}_{0}\right.$, $\mathrm{a}_{1}$ and $\mathrm{a}_{2}$, see Equation (1) for details), and root mean square of error (RMSE) for each calibration dataset

a The source of data was either farms of the network (' $S$ ' for suckler farms, ' $D$ ' for dairy farms) or the experimental farm of the CRA-W

\begin{tabular}{|c|c|c|c|c|c|c|c|}
\hline Gender & Data source $^{\mathrm{a}}$ & Breed & $\mathrm{Nb}$ & $\mathrm{LW}_{0}$ & $\mathrm{a}_{1}$ & $\mathrm{a}_{2}$ & RMSE \\
\hline \multirow[t]{6}{*}{ Male } & $\mathrm{S} 1$ & Limousin & 236 & 50 & 3.04 & 0.0037 & 38 \\
\hline & $\mathrm{S} 2$ & Salers & 5 & 45 & 3.04 & 0.0024 & 55 \\
\hline & D3 & Dairy crossbreds & 4 & 50 & 2.48 & 0.0026 & 30 \\
\hline & CRA-W & Blonde d'Aquitaine & 12 & 38 & 3.45 & 0.0024 & 70 \\
\hline & CRA-W & Mixed Belgian Blue & 46 & 50 & 3.07 & 0.0032 & 62 \\
\hline & CRA-W and S1 & Limousin & 250 & 45 & 3.02 & 0.0032 & 117 \\
\hline \multirow[t]{9}{*}{ Female } & $\mathrm{S} 1$ & Limousin & 240 & 50 & 2.72 & 0.0041 & 35 \\
\hline & $\mathrm{S} 2$ & Mixed Belgian Blue & 76 & 50 & 2.77 & 0.0025 & 92 \\
\hline & $\mathrm{S} 2$ & Salers & 30 & 45 & 2.71 & 0.0026 & 43 \\
\hline & S4 & Mixed Belgian Blue & 37 & 45 & 2.53 & 0.0026 & 63 \\
\hline & S5 & Blonde d'Aquitaine & 22 & 45 & 2.71 & 0.0028 & 53 \\
\hline & D3 & Dairy crossbreds & 80 & 45 & 2.46 & 0.0028 & 39 \\
\hline & D5 & Dairy crossbreds & 32 & 50 & 2.52 & 0.0032 & 34 \\
\hline & D6 & Dairy crossbreds & 32 & 50 & 2.61 & 0.0030 & 29 \\
\hline & D3, D5 and D6 & Dairy crossbreds & 144 & 45 & 2.52 & 0.0031 & 51 \\
\hline
\end{tabular}

explained by a relatively low growth rate of the young cattle (on average $0.54 \mathrm{~kg} \mathrm{day}^{-1}$, against 0.76 to 1.16 in the other suckler farms) and by the sale of most calves - i.e., all males and most females due to a low replacement rate - before the age of 9 months, resulting in a small proportion of one-to-two-year-old animals in the herd (on average $6 \%$ over the two monitored years, against 22, 18, 16 and $13 \%$ in farms S1 to $\mathrm{S} 4$, respectively). The animal performance in farm S1 was higher than in farm S3 because of a higher share of fattened animals among sold cattle (90 vs $28 \%$, respectively).

\section{Stocking rate}

The average stocking rate in the monitored farms was $1.1 \pm 0.2 \mathrm{LU} \mathrm{ha}^{-1}$, ranging from 0.8 (farm S3) to 1.5 (farm S1) (Table 1).

\section{Feed autonomy}

The average level of $\mathrm{FA}_{\mathrm{m}}$ was $93.7 \pm 6.2 \%$, ranging between 79.0 and $99.0 \%$ (Table 1). $\mathrm{FA}_{\mathrm{p}}$ was slightly higher than $\mathrm{FA}_{\mathrm{m}}$, with on average $94.6 \pm 6.2 \%$ and ranging from 81.9 to $100 \%$. $\mathrm{FA}_{\mathrm{m}}$ and $\mathrm{FA}_{\mathrm{p}}$ were positively correlated with each other $\left(r^{2}=0.95\right.$; $p<0.001)$. The difference between $\mathrm{FA}_{\mathrm{p}}$ and $\mathrm{FA}_{\mathrm{m}}$ in absolute value was mainly due to the relatively high protein content of grazed grass and, secondarily, to the absence of proteins in purchased feed supplements such as minerals.

Economic assessment

\section{Feed and processing costs}

Annual feed production costs were expressed, for each farm, per LU (Table 1) and per ha for each expense item (Table 3). Farms with CUAE (D5 and D6) had only grasslands resulting in low seed costs, while fees related to the CUAE included, among others, fodder storage costs, explaining the cost differences per expense item when compared with farms without CUAE (Table 3). Storage fodder costs in suckler farms were taken, at least partly, in the expenses related to the work by third parties. Feed production costs were on average $340 \pm 79 € \mathrm{LU}^{-1}$ or $379 \pm 70 € \mathrm{ha}^{-1}$ in dairy farms, and $254 \pm 49 € \mathrm{LU}^{-1}$ or $292 \pm 125 € \mathrm{ha}^{-1}$ in suckler farms. The low number of farms that were monitored in the present study, however, does not allow drawing conclusions on the cost differences among dairy and suckler farms. Feed production costs computed over all farms were $311 \pm 80 € \mathrm{LU}^{-1}$ or $350 \pm 94 € \mathrm{ha}^{-1}$. Considering the overall DM yields, they amounted to $59 \pm 18 €$ per tonne of DM, ranging from 37 (farm S3) to 94 (farm D3) $€$ per tonne of DM.

Feed purchase costs varied widely among dairy farms, ranging from 47 to $491 € \mathrm{LU}^{-1}$ 
Table 3 Costs of feed (fodder and concentrates) production by expense item for each farm over both study years (mean \pm sd)

\begin{tabular}{|c|c|c|c|c|c|c|c|c|c|}
\hline Type & Farm & Seeds & $\begin{array}{l}\text { Fertilizers } \\
\text { and amend- } \\
\text { ments }\end{array}$ & $\begin{array}{l}\text { Fodder stor- } \\
\text { age }\end{array}$ & $\begin{array}{l}\text { Fuel and } \\
\text { lubricants }\end{array}$ & $\begin{array}{l}\text { Equipment } \\
\text { and machin- } \\
\text { ery }\end{array}$ & $\begin{array}{l}\text { Work by third } \\
\text { parties }\end{array}$ & $\begin{array}{l}\text { Feeds } \\
\text { related to } \\
\text { CUAE }^{c}\end{array}$ & Total (€/ha) \\
\hline \multirow[t]{6}{*}{ Dairy } & D1 & $84 \pm 12$ & $69 \pm 1$ & $52 \pm 9$ & $55 \pm 1$ & $122 \pm 1$ & $22 \pm 9$ & - & $404 \pm 27$ \\
\hline & D2 & 72 & 133 & 15 & 43 & 65 & 104 & - & 431 \\
\hline & D3 & $124 \pm 16$ & $125 \pm 3$ & $43 \pm 3$ & $41 \pm 13$ & $83 \pm 4$ & 46 & - & $438 \pm 26$ \\
\hline & D4 & 60 & 31 & 19 & 55 & 88 & 168 & - & 422 \\
\hline & D5 & - & $52 \pm 36$ & - & $31 \pm 12$ & $1 \pm 2$ & 11 & $195 \pm 65$ & $285 \pm 22$ \\
\hline & D6 & $5 \pm 6$ & $4 \pm 4$ & $9 \pm 2$ & $29 \pm 2$ & $14 \pm 9$ & $174 \pm 67$ & 119 & $295 \pm 21$ \\
\hline \multirow[t]{3}{*}{ Suckler } & $\mathrm{S} 1$ & 97 & 8 & 7 & 55 & 92 & 148 & - & 406 \\
\hline & $\mathrm{S} 3$ & 26 & - & - & 23 & 57 & 53 & - & 159 \\
\hline & S5 & $24 \pm 14$ & - & $3 \pm 0$ & $29 \pm 0$ & $86 \pm 5$ & $170 \pm 121$ & - & $312 \pm 102$ \\
\hline Average & & $61 \pm 41$ & $60 \pm 52$ & $21 \pm 19$ & $40 \pm 13$ & $67 \pm 38$ & $100 \pm 68$ & $157 \pm 54$ & $350 \pm 94$ \\
\hline
\end{tabular}

${ }^{a}$ One single year for farms D2, D4 and S2 (year 2014) and for farms S1 and S3 (year 2015); mean \pm sd computed over 2014 and 2015 for the other farms

${ }^{\mathrm{b}} C U A E$, cooperative for the use of agricultural equipment (CUMA in French). Two farms, D5 and D6, were structured in CUAE

(mean $\pm \mathrm{sd}=171 \pm 163$; Table 1$)$. Lowest feed purchase costs were found in farm D1, which bought organic soybean meal and flaxseed cake in addition to minerals and feed supplements, and farm D2, which only bought minerals and feed supplements. Those farms were mixed crop-livestock systems characterized by a high level of $\mathrm{FA}_{\mathrm{m}}(99 \%)$. Feed purchase costs on suckler farms ranged from 21 (farm S5, only breeder) to $55 € \mathrm{LU}^{-1}$ (farm S3, breeder-fattener).

Finally, the total feed cost, including both the production and purchase of fodder and concentrates, was $511 \pm 227 € \mathrm{LU}^{-1}$ in dairy farms and $290 \pm 32 € \mathrm{LU}^{-1}$ in suckler farms. The total feed cost per $1000 \mathrm{~L}$ of milk could be computed on the three dairy farms with no suckler herd, i.e., farms D1, D5 and D6, where it was 88,102 and $95 €$, respectively (mean $\pm \mathrm{sd}=95$ $\pm 7 €$ ). Similarly, in suckler farms, the total feed cost per $100 \mathrm{~kg} \mathrm{LW}$ was 79 and $81 €$ in farms S1 and S3, respectively, two breeding-fattening farms, and $208 €$ in farm S5, an exclusively breeding farm. The comparison of these figures highlighted the presence of high charges associated with a low technical performance in farm S5 (Table 1).

Processing costs were found only in dairy farm D3, which processed milk into butter, cheese and yoghurt. They were low compared to the total considered costs (i.e., feed and processing), accounting for $1.4 \%$ of the total costs in 2014 (start year of milk processing) and for $5.5 \%$ in 2015 .

\section{Cattle-related income}

The selling price of whole milk at the dairy in the period 2014-2015 ranged from 0.414 to $0.486 €$ per litre (mean $\pm \mathrm{sd}=0.451 \pm 0.034$ ). The sales of live cattle represented $10 \pm 2 \%$ of the total annual gross product in dairy farms with no suckler herd, and $23 \pm 11 \%$ in farms with a suckler herd (D2, D3 and D4).
Table 4 Average selling prices of fattened cattle by gender and age category on monitored breedingfattening farms (prices excluding VAT) ('m' stands for months)

\begin{tabular}{llllll}
\hline Gender & Age & $\mathrm{Nb}$ of animals & $\mathrm{kg}$ carcass & $€ \mathrm{~kg}^{-1}$ carcass & $€$ animal $^{-1}$ \\
\hline Male & $\leq 8 \mathrm{~m}$ & 2 & $198 \pm 4$ & 6.3 & $1251 \pm 22$ \\
& $8-36 \mathrm{~m}$ & 20 & $446 \pm 37$ & $4.9 \pm 0.3$ & $2191 \pm 207$ \\
& $>36 \mathrm{~m}$ & 1 & 510 & 4.1 & 2075 \\
Female & $\leq 8 \mathrm{~m}$ & 1 & 176 & 6.1 & 1074 \\
& $8-36 \mathrm{~m}$ & 1 & 415 & 4.5 & 1868 \\
& $>36 \mathrm{~m}$ & 14 & $412 \pm 56$ & $4.3 \pm 0.4$ & $1793 \pm 348$ \\
\hline
\end{tabular}


The selling price of young store animals in suckler farms was $729 \pm 159$ and $710 \pm 114 €$ per animal for males $(n=118)$ and females $(n=53)$ less than 36 months of age, respectively, out of which $95 \%$ and $67 \%$, respectively, were less than 12 months of age. It was $1132 \pm 303 €$ per cull cow. The average selling price of fattened animals obtained from cooperatives of beef producers ranged from 4.1 (males over 36 months of age) to $6.3 € \mathrm{~kg}^{-1}$ carcass (male calves) (Table 4). It was intermediate for heifers and young bulls (4.5 and $4.9 € \mathrm{~kg}^{-1}$ carcass, respectively) and for cull cows ( $4.3 € \mathrm{~kg}$ carcass). Finally, the economic value of fattened animals increased from calves, male or female, to young bulls (Table 4). It was intermediate for heifers and cull cows.

\section{Economic efficiency}

EE was on average $71 \pm 11 \%$, ranging from 54 (farm D3) to $82 \%$ (farms D1 and D6; Table 1).

The relationships between economic indicators and $\mathrm{FA}_{\mathrm{m}}$

A significant negative relationship was observed between feed production costs and $\mathrm{FA}_{\mathrm{m}}\left(r^{2}=0.38\right.$, (a)

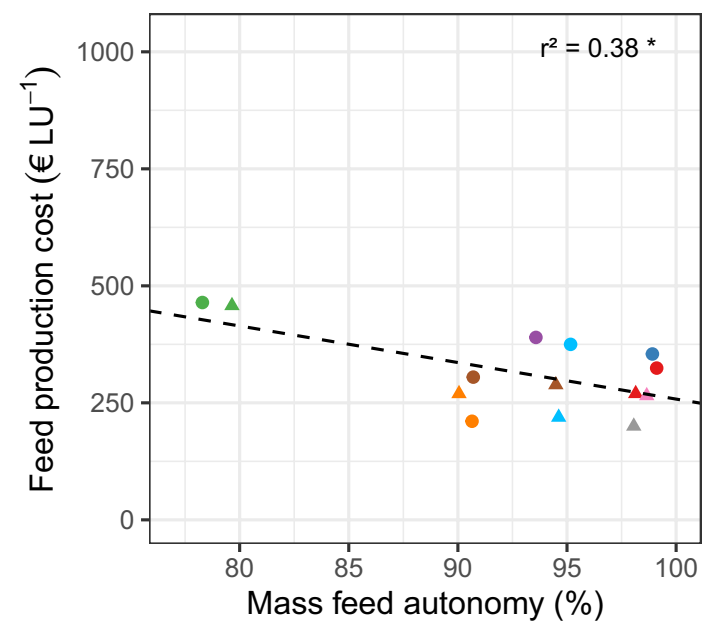

(c)

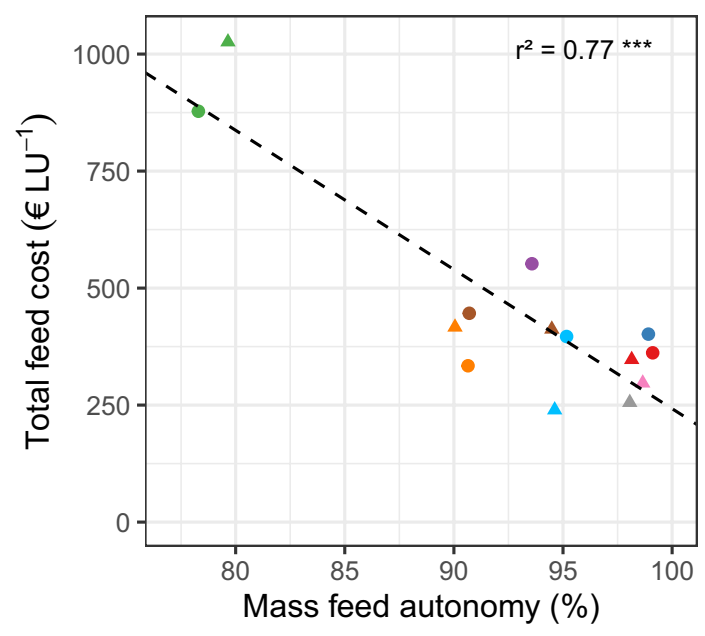

(b)

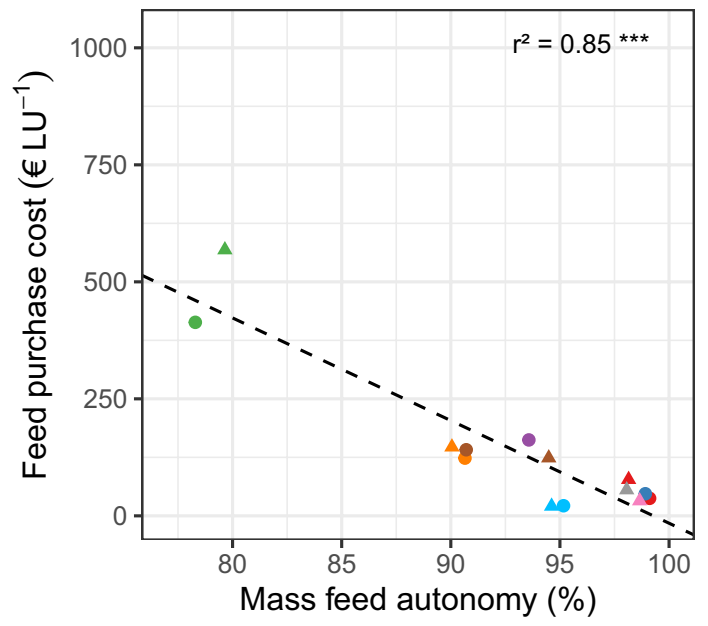

(d)

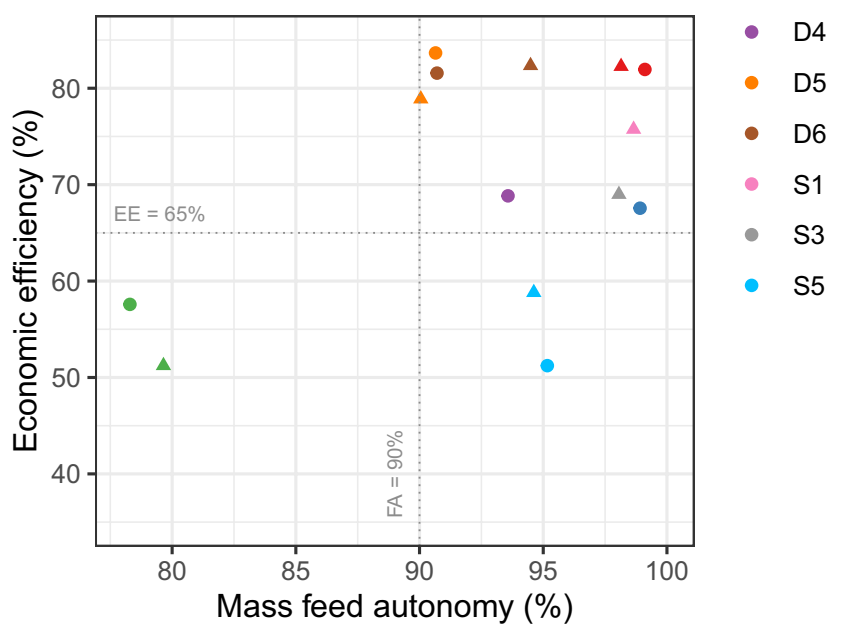

Fig. 1 Relationship between a feed production cost, $\mathbf{b}$ feed purchase cost, and $\mathbf{c}$ total feed cost per livestock unit, and mass feed autonomy, and $\mathbf{d}$ between economic efficiency and mass feed autonomy ( 6 dairy and 3 suckler farms in 2014 and/or 2015) 
$p<0.05$; Fig. 1a). This observation resulted from the relatively high feed production costs found in farm D3, which were due to large expenses in seeds and fertilizers, in particular, during both monitored years (Table 3$)$. Feed purchase costs decreased highly significantly with $\mathrm{FA}_{\mathrm{m}}\left(r^{2}=0.85, p<0.001\right.$; Fig. 1b), resulting in a decrease of the total feed cost with $\mathrm{FA}_{\mathrm{m}}$ $\left(r^{2}=0.77, p<0.001\right.$; Fig. 1c).

No overall linear relationship was found between EE and $\mathrm{FA}_{\mathrm{m}}$ (Fig. 1d). However, two observations could be made considering a threshold value of $65 \%$ for EE based on the graphical results. First, all farms with EE higher than $65 \%$ had a level of $\mathrm{FA}_{\mathrm{m}}$ higher than $90 \%$; however, not all farms with $\mathrm{FA}_{\mathrm{m}}$ higher than $90 \%$ were economically efficient at the $65 \%$ level (Fig. 1d). The relatively low EE in farm S5 (on average 55\% over both study years; Table 1) was due to high feed production costs in 2014, especially high costs of work by third parties, and to relatively low incomes in 2015 resulting from a lower number of animal sales compared to 2014 rather than from low selling prices. In farm D3, the relatively low EE (on average 54\% over both study years; Table 1) was due to large feed production costs associated with a relatively low overall DM yield in addition to large feed purchases (Fig. 1a-c; Tables 1 and 3). Second, no relationship was observed between $\mathrm{EE}$ and $\mathrm{FA}_{\mathrm{m}}$ among farms reaching a $65 \%$-level of EE (upper right sector on Fig. 1d).

Characterization of production systems with $\mathrm{EE} \geq$ $65 \%$

Economically efficient types of production systems were characterized by conducting a PCA on farms showing EE higher than $65 \%$, and thus $\mathrm{FA}_{\mathrm{m}}$ between 90 and $100 \%$ (upper right sector on Fig. 1d; 10 data points). Explanatory variables included the percentage of PG, the overall DM yield, the animal performance per cow expressed in percentage of the maximum production observed per type of farm, dairy or suckler, the stocking rate, and a binary variable indicating the soil and climate conditions that make it possible to grow grain crops or not. This variable, referred to as grain crop capacity, had a value of zero for farms D5 and D6, which were located in low mountain areas and had permanent grasslands only, and a value of one for all the other farms. Only one significant correlation was found among explanatory variables; the stocking rate increased with the overall
Fig. 2 Dispersion of farms showing an economic efficiency higher than $65 \%$ (Fig. 1d) according to the first two components resulting from principal component analysis

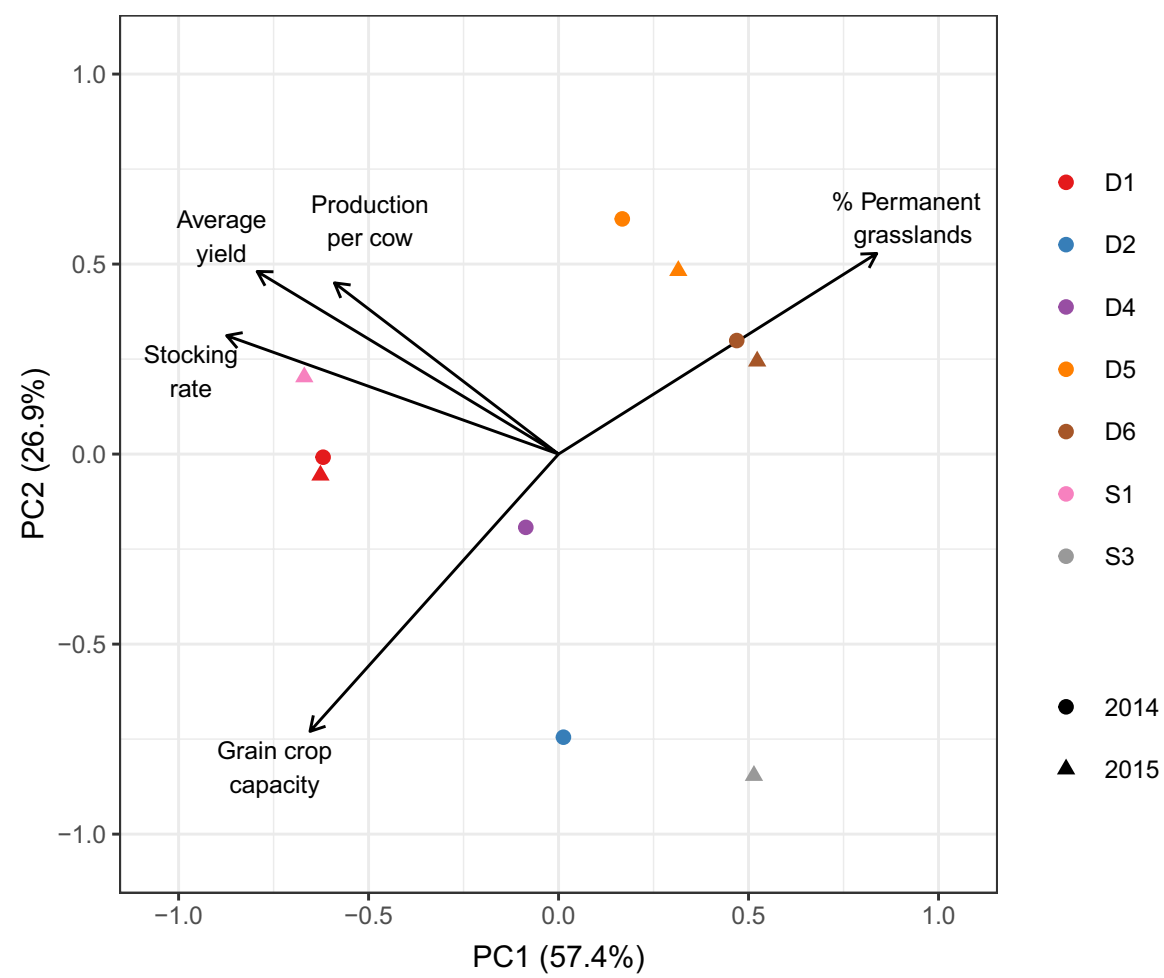




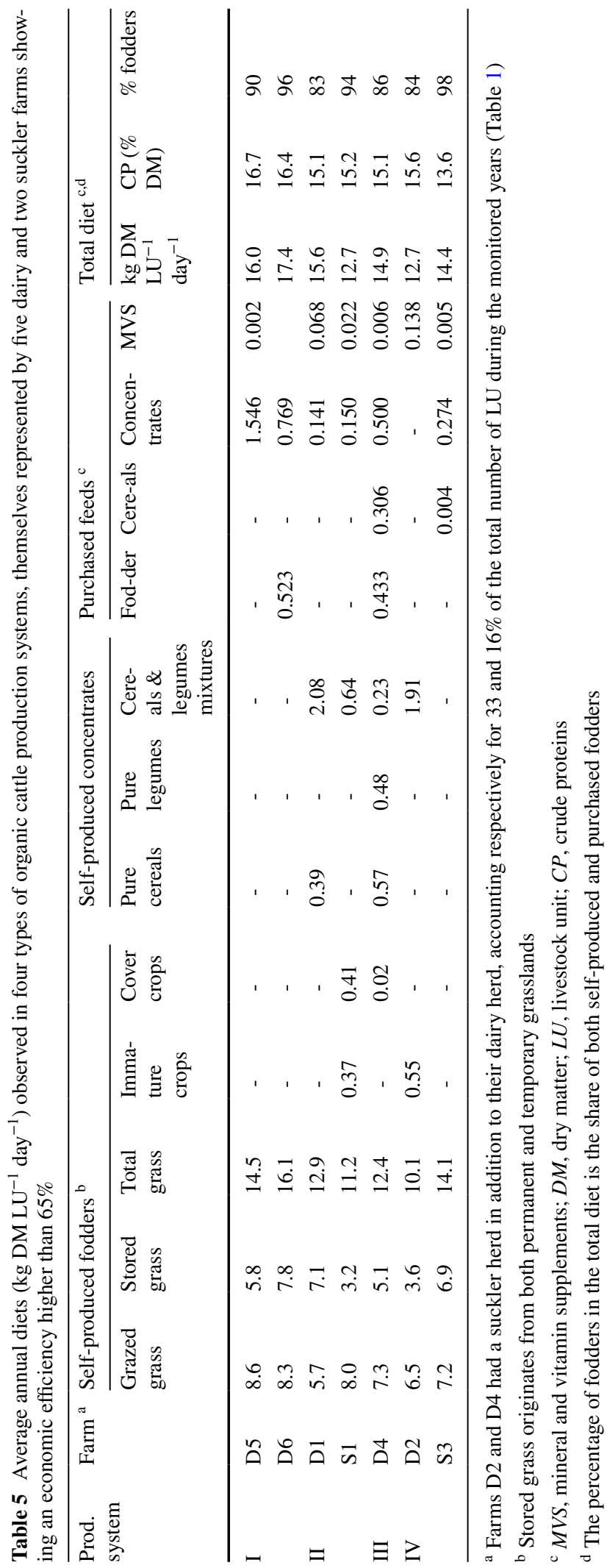


dry matter yield $\left(r^{2}=0.71 ; p<0.01\right)$. Based on the results of the PCA (Fig. 2), four types of production systems and their annual average diets (Table 5) were characterized.

\section{Production system I}

Grassland systems with relatively high animal performances, characterized by farms D5 and D6. The agricultural area includes only PG, resulting in diets characterized by a large amount of grass and by a high average protein content (on average 16.6\%; Table 5). $\mathrm{FA}_{\mathrm{m}}$ levels were 90 and $93 \%$, respectively, associated with relatively high animal performances (5515 and 5028 milk litres cow ${ }^{-1}$ year $^{-1}$ in farms D5 and D6, respectively). Overall yields (6278 and $5840 \mathrm{~kg}$ DM $\left.\mathrm{ha}^{-1}\right)$ and stocking rates (1.2 and 1.0 $\left.\mathrm{LU} \mathrm{ha}^{-1}\right)$ were slightly higher or close to the global averages ( $c f r$ supra). Purchased feeds included concentrates with a 14 to $17 \%$ protein content for lactating dairy cows and minerals.

\section{Production system II}

Mixed crop-livestock systems with relatively high animal performances and crop yields, characterized by farms D1 and S1. The share of PG in the agricultural area was relatively low (33 and 49\%, respectively). Both of these farms also produced cash crops (Table 1). $\mathrm{FA}_{\mathrm{m}}$ was high (99\%), associated with relatively high animal performances (5785 milk litres cow $^{-1}$ year $^{-1} ; 587 \mathrm{~kg} \mathrm{LW}$ cow $^{-1}$ year $\left.^{-1}\right)$, overall yields (7640 and $7031 \mathrm{~kg} \mathrm{DM} \mathrm{ha}{ }^{-1}$ ) and stocking rates (1.4 and 1.5 $\mathrm{LU} \mathrm{ha}^{-1}$ ). Purchased feeds included organic soybean meal and flaxseed cake for dairy cows in farm D1, organic finishing concentrates with a $21 \%$ protein content in farm $\mathrm{S} 1$, in addition to minerals and vitamin supplements.

\section{Production system III}

Mixed crop-livestock systems with relatively high animal performances and relatively low crop yields, characterized by farm D4. The share of PG in the agricultural area (64\%) was intermediate between production systems I and II. FA $\mathrm{m}$ was $94 \%$, associated with a relatively high animal performance (6481 milk litres cow ${ }^{-1}$ year $^{-1}$ ). The average overall yield (5409 $\left.\mathrm{kg} \mathrm{DM} \mathrm{ha}{ }^{-1}\right)$ and stocking rate $\left(1.1 \mathrm{LU} \mathrm{ha}^{-1}\right)$ were slightly lower or close to the global averages. Purchased feeds included cereal mixtures for calves and dairy cows in addition to minerals.

\section{Production system IV}

Mixed crop-livestock systems with relatively low animal performances, characterized by farms D2 and S3. This system was characterized by a high level of $\mathrm{FA}_{\mathrm{m}}$ (99 and 98\%, respectively) and lower animal performances (4029 milk litres cow $^{-1}$ year $^{-1}$; $429 \mathrm{~kg} \mathrm{LW}$ $\mathrm{cow}^{-1}$ year $^{-1}$ ), rather than by its share of PG in the agricultural area (44 and 72\%, respectively), overall yields (5631 and $4288 \mathrm{~kg} \mathrm{DM} \mathrm{ha}^{-1}$, respectively) and stocking rates (1.2 and $0.8 \mathrm{LU} \mathrm{ha}^{-1}$, respectively). Like Production system I, both of these farms had cash crops (Table 1). Farm S3 sold all its production of cereals and bought fattening concentrates with a $15 \%$ protein content in addition to minerals and supplements. Farm D2 only bought minerals and feed supplements (cod-liver oil).

\section{Discussion}

Technical assessment

Overall DM yields, computed over the whole production of fodder and concentrates (Table 1; on average $5677 \mathrm{~kg} \mathrm{DM} \mathrm{ha}{ }^{-1}$ ), were within the ranges reported in temperate regions, i.e., from 4500 to $11000 \mathrm{~kg}$ $\mathrm{DM} \mathrm{ha}^{-1}$ for PG according to weather and soil conditions (Cremer 2015) and from 2000 to $7000 \mathrm{~kg}$ $\mathrm{DM} \mathrm{ha}^{-1}$ for grain crops (Stilmant et al. 2016). The large share of grazed grass in the total self-produced DM (on average 50\%) and in the total self-produced CP (on average 61\%) highlights the importance of pasture management in enhancing the value of this resource. Also, the share of fodders (including grazed grass and stored fodders) in the average annual diets (from 83 to $98 \%$, Table 5) agreed with the minimum DM proportion of $60 \%$ from raw fodders required for organic cattle farms by the EU regulation (Commission Regulation (EC) No. 889/2008). Dairy production (on average 5326 milk litres cow $^{-1}$ year $^{-1}$ ) was in the same magnitude as the organic group described by Lebacq et al. $\left(2015 ; 5473\right.$ milk litres cow $^{-1}$ year $^{-1}$ ) or as the Mirecourt INRA organic farm (5544 \pm 570 milk litres cow $^{-1}$ year $^{-1}$ regardless of the breed and 
production system; Delaby and Fiorelli 2014). The relatively high level of dairy production observed at farm D4 might be explained, at least partly, by its dairy breed, i.e., only pure Holstein cows.

The Gompertz parameters estimated here to model the young animals' growth were in agreement with those reported by INRA (2010). Higher values were obtained for parameter $a_{1}$ given the larger LW range that was modelled here, i.e., from birth to adult weight, while INRA parameters referred to restricted growth periods (e.g., from 300 to $700 \mathrm{~kg}$, or from 500 to $750 \mathrm{~kg}$ ), resulting in $a_{1}$ values between 0.523 and 1.408. In line with INRA (2010), estimated values for parameter $a_{2}$ were higher for fattening than for growing animals (0.0036 and 0.0025 , respectively; INRA 2010) and did not differ from each other according to the gender.

LW production per LU in breeding-fattening farm S1 (376 kg LW LU ${ }^{-1}$ year $^{-1}$ ) was similar to the production level of breeding-fattening conventional systems in France (378 kg LW LU ${ }^{-1}$; Idele 2012). Performances in breeding farms S2 and S4 (232 and $238 \mathrm{~kg} \mathrm{LW} \mathrm{LU}{ }^{-1}$; Table 1) were in agreement with those observed in organic suckler systems $(250 \mathrm{~kg}$ LW LU ${ }^{-1}$; Veysset et al. 2008). Performance in farm S3 (317 kg LW LU ${ }^{-1}$; Table 1), with $28 \%$ of fattened sold cattle, was intermediate. As specified above, the low performance observed in farm S5 resulted from a relatively low growth rate of young cattle and a relatively low proportion of one-to-two-year-old cattle in that farm.

Studies on feed autonomy in Wallonia have been conducted on small numbers of conventional farms. Levels of $\mathrm{FA}_{\mathrm{m}}$ ranging between 61 and $89 \%$ have been determined on four dairy and two suckler farms $(75 \pm 11 \%)$ (Lefèvre 2016). An analysis of feed autonomy in 17 dairy and suckler farms, located in the Belgian Ardenne, led to levels of $\mathrm{FA}_{\mathrm{m}}$ of 74,79 and $82 \%$ in dairy farms $\left(1.8\right.$ to $\left.3 \mathrm{LU} \mathrm{ha}^{-1}\right)$, intensive suckler farms (2.2 to $3 \mathrm{LU} \mathrm{ha}^{-1}$ ) and extensive suckler farms (1.3 to $2 \mathrm{LU} \mathrm{ha}^{-1}$ ), respectively (Amerlynck et al. 2013). An assessment of feed autonomy conducted on a large number of cattle farms throughout France (331 suckler farms and 333 dairy farms, conventional or organic) revealed a relatively high level of $\mathrm{FA}_{\mathrm{m}}$, i.e., on average $88 \%$ (Devun et al. 2014). The level of $\mathrm{FA}_{\mathrm{m}}$ observed in the present organic farms (94 $\pm 6 \%$ ) appeared to be higher, suggesting that achieving a high level of feed autonomy is essential for the conversion of cattle farms to organic farming.

Economic assessment

An average feed cost of $122 €$ per 1000 milk litres, including feed production and purchase costs, was reported from 18 non-organic farms located in the Western Flanders and Province of Hainaut in Belgium, and in the Nord department of France (PROTECOW 2019). In France, the costs related to land supply, feed purchase and mechanization amounted to $191 €$ per 1000 milk litres in organic dairy farms located in the Hauts de France (Inosys 2018). Costs related to the same expense items ranged from 126 (steer production) to $274 €$ (calf production) per 100 $\mathrm{kg}$ LW in breeding-fattening non-organic suckler farms across France (Idele 2012). Also, costs related to the same three expense items, ranging from 144 (exclusive breeding farms) to $165 €$ (steer production) per $100 \mathrm{~kg} \mathrm{LW}$, were reported from organic suckler farms in the Pays de la Loire region of France (Inosys 2019).

Although methodological differences should be found in the computation of the feed cost between the aforementioned studies, the total feed costs per unit of product that were observed here in dairy and suckler farms (i.e., on average $95 €$ per 1000 milk litres and $80 €$ per $100 \mathrm{~kg} \mathrm{LW}$ in farms with $\mathrm{EE}>65 \%$ ) appeared relatively low. This can be explained by the high proportion of on-farm produced feed resources in the present farms. According to Idele (2012), controlling feed costs involves searching for higher autonomy in terms of both fodder and concentrates. Economic advantages of self-producing animal's feed have been demonstrated, associated with the use of fewer inputs and high-quality fodders (Lherm and Benoit 2003; Lebacq et al. 2015; PROTECOW 2018; Veysset et al. 2013). This was in agreement with the decrease of the feed purchase costs and total feed costs with $\mathrm{FA}_{\mathrm{m}}$ observed in the present study (Fig. 1b-c).

Reports on the evolution of the selling price of organic milk at dairy appeared to be very scarce. As a comparison, although for a distinct year, price for whole organic milk in the Nord department of France in 2018 was $0.476 € \mathrm{1}^{-1}$ (Inosys 2018), i.e., within the range of values reported here. Carcass prices were similar to those obtained for suckler cattle produced 
in organic conditions in Wallonia during the monitored years, i.e., 6.1 and $4.2 € \mathrm{~kg}^{-1}$ for calves under 8 months old and for young bulls, respectively (Decruyenaere, unpublished data).

Economic efficiency, defined as the ratio between the net economic output produced per unit of gross product, has been used as an indicator of vulnerability to climate and economic variations (Martin et al. 2017). Measurements of EE revealed values ranging between 46.6, 51.5 and $56.8 \%$ for beef, mixed and dairy systems, respectively (Martin et al. 2017). The threshold value of $65 \%$ that was used here while considering only the feed and product processing costs was thus higher than the reported EE measurements and therefore considered as acceptable. However, additional farm*year data points should be required to refine this threshold value.

The relationships between economic efficiency and $\mathrm{FA}_{\mathrm{m}}$

All farms with $\mathrm{FA}_{\mathrm{m}}$ higher than $90 \%$ but one (farm S5) had EE higher than 65\%, while no relationship was observed between $\mathrm{EE}$ and $\mathrm{FA}_{\mathrm{m}}$ among farms reaching a $65 \%$-level of EE (Fig. 1d). These observations suggested that achieving a $90 \%$ level of $\mathrm{FA}_{\mathrm{m}}$ is necessary but not sufficient to be economically efficient at the $65 \%$ level, while beyond $90 \%$ of $\mathrm{FA}_{\mathrm{m}}$ increasing $\mathrm{FA}_{\mathrm{m}}$ is not necessarily economically efficient. These results are in agreement with previous studies that highlighted the economic importance of feed autonomy in organic cattle or sheep production systems (Veysset et al. 2008; Pottier et al. 2009; Lebacq et al. 2015; Experton et al. 2017) while noting that purchasing concentrates, even at a high price, can be economically justified if the demand and price for the product are high (Veysset et al. 2013).

Among the monitored farms, the low EE observed in farm D3 could be improved through a better management of feed production costs (Table 3) and through a decrease of herd size or animal performance in order to reduce the need for feed purchases. In farm S5, EE could be improved through a better management of feed production costs and, possibly, through increased young cattle's performances if this leads to higher selling prices. Although a level of $\mathrm{FA}_{\mathrm{m}}$ equal or higher than $90 \%$ is not a guarantee of profitability, it seems to be a necessary step to reach economic profitability in organic cattle farms.
Characterization of production systems with $\mathrm{EE} \geq 65 \%$

The positive correlation that was observed between stocking rate and overall yield suggested the search for a correspondence between cattle feeding needs and the production capacity of the environment, defined by its soil and climate conditions in particular. This observation can be related to the concept of management practices that evolve with the aim of self-sufficiency in a fluctuating environment and following the perceptions of the systems' actors, i.e., here the farmers (Coquil et al. 2011). According to Coquil et al. (2011), such evolutions might be either necessary to sustain the system when facing operational difficulties or might be promoted in order to improve the system's economic results, as observed by Pottier et al. (2009) in organic cattle systems.

The total amounts of DM available per LU and per year were slightly lower than those reported by Devun et al. (2014) in conventional farming systems (on average 16.9 and $14.9 \mathrm{~kg} \mathrm{DM} \mathrm{LU}^{-1}$ day $^{-1}$ for dairy and beef systems, respectively, against, on average, 15.3 and $13.6 \mathrm{~kg} \mathrm{DM} \mathrm{LU}^{-1}$ day $^{-1}$ in the present study). In contrast, the amount of grass (both grazed and stored) in the daily diets of grassland systems (Production system I; Table 5) was higher than that reported for grassland dairy systems $\left(13.2 \mathrm{~kg} \mathrm{LU}^{-1}\right.$ day $^{-1}$ against 14.5 and $16.1 \mathrm{~kg} \mathrm{DM} \mathrm{LU}^{-1} \mathrm{day}^{-1}$ in the farms monitored here; Devun et al. 2014). A similar observation was made with mixed crop-livestock systems. Indeed, the total amount of grass in daily diets of Production systems II and III (Table 5) was slightly higher than the values reported by Devun et al. (2014) for grass-based systems with self-production of concentrates (i.e., $11.6 \mathrm{~kg} \mathrm{DM} \mathrm{LU}^{-1}$ day $^{-1}$ from grass in mixed crop-grassland dairy farms, and $10.4 \mathrm{~kg} \mathrm{DM}$ $\mathrm{LU}^{-1} \mathrm{day}^{-1}$ from grass in breeding-fattening farms with crops). In terms of milk production, the levels observed in Production system I, with only PG (on average 5272 litres cow $^{-1}$ year $^{-1}$ ), vs Production systems II and III, both characterized by the presence

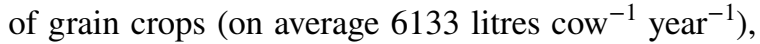
were comparable to those observed at the Mirecourt organic farm of INRA, i.e., 5637 vs 6302 milk litres cow $^{-1}$ year $^{-1}$ with Holstein cows and 5025 vs 5207 with Montbeliarde cows in the grassland-based system vs mixed crop-livestock system (Delaby and Fiorelli 2014). 
Production system IV was characterized by lower animal performance. Among the two farms of this production system, farm D2 had a specific underlying feeding strategy, i.e., the search for a complete autonomy in fodders and concentrates. This feeding strategy is in line with the strategy experimented at the Mirecourt organic farm of INRA, i.e., producing milk in complete autonomy in straw and in feed (Coquil et al. 2009). The animal performance that was observed at farm D2 was nevertheless lower than those observed at the Mirecourt farm, as reported above (Delaby and Fiorelli 2014). This might be, at least partly, explained by the lower amount of DM available per LU (Table 5). The total amount of grass in the daily diets was close (farm D2) or higher (farm S3) than the values reported by Devun et al. (2014) for mixed crop-grassland systems. Additional surveys of feed autonomy in organic cattle farms would be necessary to ascertain the definition of this production system.

\section{Organic cattle production and feed-food competition}

In cattle farms with arable land, the competition between feed and food crops may be questioned. From an economic perspective, the decision depends, in particular, on the market price of organic concentrates and on the selling price of organic cereals, both of which being relatively high [e.g., $402 € \mathrm{t}^{-1}$ for organic bread wheat (BioWallonie 2021), $535 € \mathrm{t}^{-1}$ for an organic finishing concentrate with a $14 \%$ protein content]. In a context of high prices for organic cereals, farmers could have interest in reducing their number of cows and increasing their production of cereals, as long as the overall balance of the system allows for it, in particular, in terms of organic fertilization (Benoit and Veysset 2003).

Grass-based cattle production systems have been recognized for their relatively low competition with human food because of a relatively low share of human-edible feed in the diets (Battheu-Noirfalise et al. 2019; Laisse et al. 2018; Madeline et al. 2020). However, they often need larger areas than systems using more concentrates, while some grassland areas can be converted to arable land and thus compete with human food (Madeline et al. 2020). The humanedible feed conversion efficiency of organic dairy and beef products could be improved by integrating organic by-products in diets, which will depend on their local availability, nutritional value, and market price (Laisse et al. 2018).

Four out of the eleven monitored farms produced crops for sale in addition to cattle (Table 1). Simulation studies would however be needed to find out the optimal crop rotation and animal production level for each of the monitored farms taking into account the economic context, their feed conversion efficiency and land use per $\mathrm{kg}$ of consumed human-edible proteins, and agronomical concerns in terms of nitrogen supply, in particular. According to Madeline et al. (2020), land use by organic cattle farms should be discussed in relation to the externalities of organic farming, by considering environmental impacts in terms of biodiversity, water quality, product quality, farmers' income or human health.

\section{Conclusion}

This study characterized the technical and economic performances of eleven organic cattle farms and identified four types of production systems showing economically efficient feeding strategies. These production systems were characterized by large amounts of grass, grazed or stored, in the diets. The results highlight the importance of adapting the herd size and performance to the feed production capacity to achieve a level of feed autonomy between 90 and $100 \%$. However, the feeding strategy to be adopted, and resulting level of feed autonomy, depend on the land use and production potential (percentage of PG, capacity to grow grain crops, overall DM yield), which are linked to the local soil and climate conditions, and on the targeted animal performance.

From a methodological point of view, this study was aimed at characterizing a diversity of Walloon dairy and/or suckler cattle production systems under organic management conditions. The small number of monitored farms raises the question of the acquisition of data from commercial farms to conduct studies aimed at characterizing the functioning of production systems. In practical terms, such studies require a technician to monitor the crop, livestock and economic performances of the farms. Regional research projects usually support funding for monitoring a limited number of farms (less than 20). In this context, global studies on feed autonomy in organic cattle 
farms, including modelling studies, would need the integration of data from different research projects.

Finally, the present paper (i) highlighted the importance of a high level of feed autonomy in organic cattle farms, and (ii) offers technical and economic references, in particular, for further studies aimed at optimizing the economic and environmental performances of organic cattle systems.

Acknowledgements We gratefully thank the eleven farmers who took part in the present study.

Funding We gratefully thank the Service Public de Wallonie, Direction Générale de l'Agriculture, des Ressources naturelles et de l'Environnement for funding (Walloon research programme in Organic agriculture BIO2020).

Data availability The datasets generated during and/or analysed during the current study are available from the corresponding author on reasonable request.

\section{Declarations}

Conflict of interest The authors declare no conflict of interests.

Open Access This article is licensed under a Creative Commons Attribution 4.0 International License, which permits use, sharing, adaptation, distribution and reproduction in any medium or format, as long as you give appropriate credit to the original author(s) and the source, provide a link to the Creative Commons licence, and indicate if changes were made. The images or other third party material in this article are included in the article's Creative Commons licence, unless indicated otherwise in a credit line to the material. If material is not included in the article's Creative Commons licence and your intended use is not permitted by statutory regulation or exceeds the permitted use, you will need to obtain permission directly from the copyright holder. To view a copy of this licence, visit http://creativecommons.org/licenses/by/4.0/.

\section{References}

Amerlynck D, Bernes A, Cremer S, Decruyenaere V, Francard F, Jamar D, Knoden D, Lambert R, Stilmant D, Widar J (2013) Autonomie alimentaire dans une region herbagère. Le cas du Parc naturel Haute-Sûre Forêt d'Anlier. 40 pages

Battheu-Noirfalise C, Stilmant D, Reding D, Wyzen B, Wester J, Mathot M, Hennart S, Decruyenaere V (2019) Net contribution of dairy production to food supply: impact of intensification and grassland share. Book of Abstracts of the $70^{\text {th }}$ Annual Meeting of the European Federation of Animal Science, Ghent, Belgium, 26-30 August 2019

Benoit M, Veysset P (2003) Conversion of cattle and sheep suckler farming to organic farming: adaptation of the farming system and its economic consequences. Livestock Prod Sci 80:141-152

BioWallonie (2021) Le cours des prix des céréales et légumineuses $\mathrm{BIO}$ à votre portée. https://www.biowallonie. com/mercuriales-des-prix/. Newsletter from February 2021. Accessed 7 May 2021

Charroin T, Ferrand M, Membres des réseaux d'élevage (2010) Elaboration d'un jeu de coefficients pour analyser les coûts de structure d'une exploitation - Application aux charges de mécanisation des systèmes de polyculture-élevage. Renc Rech Ruminants 17:413-416

Coquil X, Blouet A, Fiorelli J-L, Bazard C, Trommenschlager J-M (2009) Conception de systèmes laitiers en agriculture biologique: une entrée agronomique. INRA Prod Anim 22:221-234

Coquil X, Fiorelli J-L, Blouet A, Trommenschlager J-M, Bazard C, Mignolet C (2011) Conception de systèmes de polyculture élevage laitiers en agriculture biologique: Synthèse de la démarche pas à pas centrée sur le dispositif expérimental INRA ASTER-Mirecourt. Renc Rech Ruminants 18:57-60

Cremer S (2015) La gestion des prairies. Notes de cours 20152016. Fourrages-Mieux. 133 pages

DAEA (2009) Harmonisation des concepts dans les comptabilités analytiques agricoles en Wallonie. Version 3.0. Service Public de Wallonie, Direction de l'Analyse Economique Agricole. 35 pages

De Brabander D, De Campeneere S, Ryckaert I, Anthonissen A (2011) Melkveevoeding. ILVO Mededeling 101. 112 pages

Decruyenaere V, Agneessens R, Toussaint B, Anceau C, Goffaux M-J, Oger R (2006) Qualité du fourrage en Région Wallonne. REQUASUD. 32 pages

Decruyenaere V, Fabry J, Lecomte Ph, Sindic M, BartiauxThill N (1999) Finition de la vache de réforme de type Blanc-Bleu-Belge culard (BBB): engraissement à l'auge ou à la prairie; performances zootechniques et qualité de la viande. Renc Rech Ruminants 6:274

Delaby L, Fiorelli J-L (2014) Elevages laitiers à bas intrants : entre traditions et innovations. INRA Prod Anim 27:123-134

Delagarde R, Caillat H, Fortin J (2017) HerbValo, une méthode pour estimer dans chaque parcelle la quantité d'herbe valorisée par les ruminants au pâturage. Journées de Printemps de l'AFPF, Paris, pp 117-124

Devun J, Brunschwig P, Guinot C (2014) Alimentation des bovins : rations moyennes et autonomie alimentaire. Viandes \& Produits Carnés 30:1-9

Duru M, Bastien D, Froidmont E, Graulet B, Gruffat D (2017) Importance qualitative et quantitative des produits issus de bovins au pâturage sur les apports nutritionnels et la santé du consommateur. Journées de printemps de l'AFPF, Paris, pp 35-48

Experton C, Bellet V, Gac A, Laignel G, Benoit M (2017) Miser sur l'autonomie alimentaire et les complémentarités entre régions pour assurer la rentabilité de l'élevage ovin allaitant biologique et conforter les filières. Fourrages 231:223-234

Faux J (2016) Essais sur l'autonomie alimentaire en élevage limousin et en engraissement de volailles fermières. 
Rapport final du Centre de Référence et d'Expérimentation de Wallonie 2013 - 2015. 99 pages

Hoch T, Pradel P, Agabriel J (2004) Modélisation de la croissance de bovins : évolution des modèles et applications. INRA Prod Anim 17:303-3014

Hubrecht L, Willems W, Fiems L (2013) Voeding van runderen van het Belgische witblauwe ras. Vlaamse overheid. 88 pages

Idele (2012) Les coûts de production dans les élevages bovins viande. Enquête annuelle 2011 des réseaux d'élevage. Collection Théma, Institut de l'élevage. 20 pages

Inosys (2018) Bovins Lait. Les systèmes bovins laitiers en Hauts-de-France. Repères techniques et économiques 2017/2018. Collection Résultats. 10 pages

Inosys (2019) Coûts de production des ateliers bovins viande en agriculture biologique. Résultats de 2015 à 2017. 4 pages

INRA (2010) Alimentation des bovins, ovins et caprins: Besoins des animaux - Valeurs des aliments. Editions QUAE, Versailles

Laisse S, Baumont R, Dusart L, Gaudré D, Rouillé B, Benoit M, Veysset P, Rémond D, Peyraud J-L (2018) L'efficience nette de conversion des aliments par les animaux d'élevage: une nouvelle approche pour évaluer la contribution de l'élevage à l'alimentation humaine. INRA Prod Anim 31:269-288

Lebacq T, Baret PV, Stilmant D (2015) Role of input self-sufficiency in the economic and environmental sustainability of specialised dairy farms. Animal 9:544-552

Lefèvre A (2016) Rapport de synthèse du projet "Plan global de Recherche Autonomie Protéique" (D31-1317). Centre wallon de Recherches Agronomiques. 124 pages

Lherm M, Benoit M (2003) L'autonomie de l'alimentation des systèmes d'élevage allaitant: évaluation et impacts économiques. Fourrages 176:411-424

Madeline L, Mottet A, Poyard E, Veysset P (2020) Efficience alimentaire des élevages bovins en agriculture biologique et compétition avec l'alimentation humaine. Innovations Agronomiques 79:413-424

Martin G, Magne M-A, San Cristobal M (2017) An integrated method to analyze farm vulnerability to climatic and economic variability according to farm configurations and farmers' adaptations. Front Plant Sci 8:1483

MCMA (1993) L'alimentation de la vache laitière. $4^{\text {ième }}$ édition revue. Ministry of Agriculture, Information Service ed., Bruxelles

MCMA (1996) La vache allaitante. Ministry of Agriculture, Information Service ed., Bruxelles

MecaCost (2021) Mecacost Software. Running costs for tractors and agricultural machines. CRA-W, Gembloux, Belgium. https://www.mecacost.cra.wallonie.be/en. Accessed 7 May 2021
Paccard P, Capitain M, Farruggia A (2003) Autonomie alimentaire des élevages bovins laitiers. Renc Rech Ruminants 10:89-92

PDZR (1996) Produire de la viande de qualité en Région wallonne. Plan de développement en Zones rurales. Fiche Alimentation

Pottier E, Prache S, Benoit M, Tournadre H (2009) Maximiser la part du pâturage dans l'alimentation des ovins : intérêt pour l'autonomie alimentaire, l'environnement et la qualité des produits. Fourrages 199:349-371

PROTECOW (2018) Fiche $\mathrm{N}^{\circ} 3$ - La qualité de la protéine. www.inter reg-protecow.eu/documenten-documents/. Accessed 31 March 2020

PROTECOW (2019) Comparer les marges brutes des éleveurs wallons, français et flamands. https://www.interreg-prote cow.eu/actua-actualités/. Accessed 31 March 2020

R Core Team (2018) R: a language and environment for statistical computing. R Foundation for Statistical Computing, Vienna, Austria. URL https://www.R-project.org/

Rouillé B, Devun J, Brunschwig P (2014) L'autonomie alimentaire des élevages bovins français. OCL 21:D404

Sepchat B, D'hour P, AgaBriel J (2017) Production laitière des vaches allaitantes : caractérisation et étude des principaux facteurs de variation. INRA Prod Anim 30:139-152

Stilmant D, Seutin Y, Clement C, Pitchugina E, Planchon V, Jamar D (2016) Impact of $\mathrm{N}$ fertilisation and legume sowing density on cereals - peas intercropping performances. Grassland Science Europe 21:427-429

Tamminga S, Van Straalen WM, Subnel APJ, Meijer RGM, Steg A, Wever CJG, Block MC (1994) The Dutch protein evaluation system: the DVE/OEB-system. Livestock Prod Sci 40:139-155

Van Es AJH (1975) Feed evaluation of dairy cows. Livestock Prod Sci 2:95-107

Veysset P, Benoit M, Belveze J, Patout O, Reuillon JL, Morin E, Vallas M (2013) Autonomie alimentaire en élevages bovins et ovins biologiques du Massif Central: résultats, pratiques et perceptions par les éleveurs. Renc Rech Ruminants 20:295

Veysset P, Glouton J, Bébin D, Bécherel F (2008) Elevage de bovins allaitants en agriculture biologique dans le Massif Central : analyse des résultats technico-économiques. Innovations Agronomiques 4:135-144

Publisher's Note Springer Nature remains neutral with regard to jurisdictional claims in published maps and institutional affiliations. 